\title{
Positiivisuuden ja onnellisuuden kultista ja markkinafundamentalismista
}

Tommi Melender (2016). Onnellisuudesta. WSOY. 183 s. ISBN: 9789510412251

TOMMI MELENDER KIRJOITTAA kirjassaan Onnellisuudesta esseitä, mikä on kirjallisuudenlajeista kaikkein vaativin ja henkilökohtaisin. Esseille on ominaista itsetutkiskelu, ja esseistin tärkeimpiin hyveisiin kuuluu kyky myös eksyä aiheestaan. Emme aina tule oivaltaneeksi lajityypin ominaisluonnetta, kun pyydämme opiskelijoiltamme kirjoittamaan opintosuorituksena esseen. Se tarkoittaa ranskalaisen alkusanansa mukaisesti yritelmää, joka ei pakota itseään kokoaviin loppupäätelmiin. Esseille on ominaista eteneminen kirjoittajaa omakohtaisesti koskettaviin aihepiireihin.

Melenderillä esseiden aiheet vaihtelevat porvarillistuneesta onnellisuuden myyteistä rahaan ja vapauteen, kirjallisiin esikuviin, kirjailijakohtalon ja kirjailijakutsumuksen pohtimiseen, lyriikkaan ja runouteen, miehisyyteen ja jalkapallon merkitykseen onnellisuuden ja jaetun yhteisöllisyyden tuottaja- na. Kiinnostavaa on, miten sukupuolisensitiivisesti hän kirjoittaa puhuessaan kirjailijan kutsumuksestaan. Menender erottautuu kirjassaan tarkasti ja selvin sanoin onnellisuusguruista ja onnellisuusoppaista, joiden avulla markkinaliberalistisessa ajassa ihmispolot yrittävät lisätä elämänhallintaansa ja hankkia rahaa, ystäviä ja vaikutusvaltaa. Menenderin päätavoitteena on kirjoittaa omakohtaisesti ja tavalla, jonka toivoo samalla herättävän lukijoissa tunnistamisen kokemuksen.

Kirjoittaja kokoaa esseidensä annin kirjansa lopussa melankolian puolustukseksi. Melankolinen mielenlaatu nykyisen positiivisuuden myytin ja posetiivarikonsulttien kulta-aikana on kadottamassa olemassaolon oikeutensa. Lauren Berlantiin "julman optimismin" mukaisesti pettymyksen, tuskan, kivun ja kärsimyksen tunnistaminen ei ole pakotetun optimismin aikana hyväksyttävää tai sallittua. Kun espoolaisen keskijohdon pomo, joka harrastaa purjehdusta, äänestää kokoomusta ja käy henkisessä valmennuksessa, esimerkiksi konkurssin, avioeron tai lopputilin myötä joutuu tilanteeseen, jossa unelmat nyrjähtävät pakoiltaan, tarvitaan silloin posetiivarikonsulttien ja elämäntaidon gurujen mukaan ennen kaikkea itsensä johtamisen taitoa. Positiivisen ajattelun pärjäämisen eetoksen mukaisesti yksilö tarvitsee vaikka hammasta purren vain entistä suurempaa positiivisuutta. Jälkiteollisen kapitalismin johtolauseen Melender tiivistääkin lauseeseen: ”Hän popsi masennusläk̈keitä ja luki onnellisuusoppaita".

\section{VAIHTOEHTO MENESTYKSEN} TAVOITTELUN EETOKSELLE

Melenderin markkinafundamentalismin esiin ruoskiman onnelli- 
suuden ja positiivisuuden kultin ruumiinavaus synnyttää esseitä lukiessa uudenlaista hengittämisen tilaa ja helpottavaa myötäelämisen tunnetta. Pakotetun ja pinnistellyn hymynaamarin ylläpitämisen sijasta meidän olisikin ehkä syytä paneutua elämän traagiseen perusluonteeseen. Sanoma on täysin päinvastainen, kuin esimerkiksi Alexander Stubbin, joka kehottaa meitä unelmoimaan aina suurista asioista sanoen: "Uskokaa itseenne, niin kaikki on mahdollista”. Menender nimeää Stubbin läntisille yhteiskunnille ominaisen uushengellisyyden edustajaksi.

Stubbissa henkilöityy uususkonnollisuus, joka on tyypillistä laajemminkin politiikan ja yritysmaailman eliitin maailmankuvalle. Jos et pysty loistamaan positiivisuuden päivänsäteiden ja huippusuoriutujien tapaan Oy Minä Ab:n ruokkimassa itsensä johtamisen ja "ja tsemppihömpän" ilmapiirissä, saatat osoittautua suorastaan "mädäksi omenaksi", josta on päästävä eroon. Voit muuten vahingossa tai jopa täysin tietoisesti pilata tulevien huippusuoriutujien virettä, tunnelmaa ja kansallisen kilpailukyvyn nostatusta. Posetiivarikonsulttien markkinafundamentalismin tunnelmista Menender johdattaa meitä Antiikin onnellisuuden ideoihin hyveen noudattamisesta ja henkisten voimavarojen ja potentiaalien löytämisen prosesseista. Näitä hän nostaa eräänlaiseksi vaihtoehdoksi nykyiselle porvarilliselle menestyksen tavoittelun eetokselle.
Menender kirjoittaa omista kirjallisista esikuvistaan ja kirjailijaksi kasvun prosessistaan. Hän kertoo, miksi kirjallisuuden lukeminen on ollut hänelle tärkeää ja miksi lukuharrastus voi olla yleisemminkin ihmiselle tärkeää. Hän johdattaa lukijat pohtimaan, millainen merkitys kirjallisuudella voi olla "uuden hyödyn" aikakautena. Menenderin tärkeä kirjallinen esikuva Flaubert hyökkää näkyvästi älyllistä latteutta, typeryyttä ja henkistä keskinkertaisuutta vastaan ja puoltaa provokatiivisesti taiteen ja kirjallisuuden hyödyttömyyden oikeutusta. Kysymys hyödystä on tärkeä ja liittyy taiteen ja kirjallisuuden yhteiskunnalliseen ja moraaliseen riippumattomuuteen.

\section{SIVISTYKSEN HYÖTYPUHE}

Tällä uuden hyödyn aikakaudellamme kirjailijat ja kulttuurin edustajat sortuvat Menenderin mukaan eräänlaiseen lobbariretoriikkaan. He ovat ryhtyneet puolustautumisreaktiona mainostamaan taiteen ja kulttuurin hyödyllisiä hyvinvointivaikutuksia. Tämä Menenderin sinkoama nuoli (ks. myös Filander 2015) osuu myös vapaan sivistystyön tutkijakehittäjiin, jotka viime vuosina ovat nostaneet näkyvästi esille "sivistyshyödyn" käsitteen ja esimerkiksi sivistystyön laaja-alaiset terveysvaikutukset (ks. esim. Schuller ym 2001; Manninen \& Luukannel 2008; Manninen 2010; Jokinen, Poikela \& Sihvonen 2012, Harju 2013).

Talouspuheen ja uuden hyödyn aikakaudella on ikään kuin pakko noudattaa hegemonistisen talouspuheen kielioppia, että voisi edes jotenkin tulla kuulluksi. Uuden hyödyn ja talouspuheen dominanssi on vallitseva tila myös yliopistoissa, joiden tehtäviä ja tarkoitusta tyydytään pääosin perustelemaan talouden kansallisen kilpailukyvyn hyötyvaikutuksilla. Hyötypuheen ylittävää ymmärrystä yliopistoista onkin vaikea löytää. (ks. Filander 2016.) Menender viittaa Flaubertiin todetessaan, että nykyajan "tolvanat" ja porvarit mittaavat sivistyksen ja oppineisuuden vain rahassa käyttäen sellaisia kuvaavia kiertoilmaisuja kuin "huippuosaaminen" ja "inhimillinen pääoma". Kuulostaako tutulta?

\section{PARHAIMMAN LUOKAN ESSEEPROOSAA}

Menender kertoo kirjansa taustakertomuksena omakohtaista elämäntarinaa siitä, miten hän on kehittynyt ja muuttunut ihmisenä eri elämänvaiheissaan ja millainen kirjallisuus häntä on eri elämänvaiheissa erityisesti puhutellut. Kun Faubert houkutteli häntä kirjallisuuden opiskelijana ihmisvihaan ja kääntämään selkänsä kanssaihmisille, niin Camus auttoi ojentumaan toisia ihmisiä kohden. Camusin ajatus siitä, että on luotava onnea protestiksi universumin onnettomuudelle puhuttelee myös lukijaa. Samoin ajatus, jonka mukaan kapina kaiken merkityksettömyyttä vastaan riittää jo täyttämään sydämemme onnellisuudella. Solidaarisuus ja vuoropuhelu voivat olla sanka- 
ruutta ilman mahtipontisuuden painolastia, joka auttaa protestoimaan eripuraisen maailman onnettomuuksia vastaan.

Henkisestä alaikäisyydestä itsensä järjenkäyttöön vapauttamisen prosessi, joka on toiminut valistuksen ideaalina ja onnellisuuden mittana, on markkinafundamentalismissa korvautunut markkinatalouden haluilla ja vasta toissijaisesti tarpeillamme.

Applen perustajan Steve Jobs tiivistää hyvin edellä todetun: ”Asiakkaat eivät tiedä, mitä tarvitsevat ennen kuin me näytämme heille, mitä he tarvitsevat”. Markkinatalouden ihmisyyttä alistavaa ja manipuloivaa halujen ohjailua vastaan tarvitaan juuri yliopistoja ja vapaata sivistystyötä. Näiden vaikutuspiirissä on parhaimmassa tapauksessa mahdollista kehittää hyötypuheelle vaihtoehtoista kieltä ja kielioppia. Menenderin esseekokoelman oivallukset voi- vat palvella myös tätä tarkoitusta. Melenderilla on kyky tarttua itseään koskettaviin aiheisiin tavalla, joka synnyttää oikeasti lukijassa myös tunnistamisen kokemuksen. Kyse on parhaimman luokan esseeproosasta, jonka kirjoittaja pystyy kirjoittamalla itsestään auttamaan samanaikaiseksi myös lukijaa ymmärtämään paremmin omaa elämäntilannettaan.

\section{Karin Filander}

\section{LÄHTEET}

Filander, K. (2015) Kansan paluu vapaaseen sivistystyöhön. Julkaisussa Pätäri, J., Turunen, A. \& Sivenius A. (toim.) Vapaa, vallaton \& vangittu sivistystyö. Sivistystyön vapaus ja vastuu -pamfletti 2015. http:// www.vapausjavastuu.fi/wp-content/ uploads/2014/05/SVV_pamfletti_ Tulostettava.pdf, s. 43-53.

Filander, K. (2016) Yliopistojen moraalijärjestys ja toimijuuden ehdot- Miten rakentaa vaihtoehtoja vaihtoehdottomuuteen? Tiedepolitiikka 2/2016, Teemalehti
Akateeminen työ- vaihtoehtoja vaihtoehdottomuuteen? 9-20 Harju A. (2013) Sivistystyön yhteiskunnallinen ulottuvuus. Teoksessa Teoksessa Harju.A. \& Rantala, J. (toim.) (2013) Sivistymisen idea - Vapaan sivistystyön eetosta etsimässä. Helsinki: Sivistysliitto Kansalaisfoorumi, 144-188. Jokinen, J. Sihvonen J. \& Poikela, E. (2012) Sivistyshyöty ja sosiaalinen pääoma vapaassa sivistystyössä. Helsinki: VSY. http://www.vsy.fi/doc/ SIVISTYSHjasopo2012.pdf

Manninen, J. \& Luukannel S. (2008)

Omaehtoisen aikuisopiskelun vaikutukset. Vapaan sivistystyön opintojen merkitys ja vaikutukset aikuisten elämässä. Helsinki: VSY, Vapaan sivistystyön yhteisjärjestö. Manninen, J. (2010) Sopeuttavaa sivistystyötä? Aikuiskasvatus 30(3), 164-174.

Schuller, T. Bynner, J, Green, A., Blackwell, L., Hammond, C., Preston, J. \& Gough, M. (2001) Modelling and Measuring the Wider Benefits of Learning: A Synthesis. The Wider Benefits of Learning Papers. No.1, London: Institute of Education/Birkbeck. 